\title{
Kereszténység és emberi jogok - az emberi méltóság nézőpontjából
}

\section{BALOGH ZSOLT PÉTER ${ }^{1}$}

A tanulmány bizonyitani igyekszik, hogy a vallási meggyőzödéssel élö embert nem távolitani kell az emberi jogok rendszerétöl, hanem épp ellenkezöleg, közeliteni kell felé. Az emberi jogok a Teremtö adta emberi szabadságból erednek, minden jog mélyén megtalálható az emberi méltóság. Az emberi jogok az embertöl elválaszthatatlan olyan természetes és elidegenithetetlen jogok, amelyeknek tápláléka a keresztény szabadságeszme is. A tanulmány foglalkozik a személyiségvédelemmel, érinti a magánszféra védelmét, az egyenlöség problémáját, valamint arra a megállapitásra jut, hogy az emberi jogok alatt bizonyos szociális jogokat is érteni kell a keresztény szellemü megközelités alapján.

Kulcsszavak: emberi jogok, emberi méltóság, kereszténység, személyiségvédelem, magánszféra védelme, egyenlőség, szociális jogok

\section{Christianity and Human Rights - An Aspect of Human Dignity}

The aim of this work is to prove that the system of human rights is not far from religious beliefs, furthermore, they belong together. The basis of human rights comes from the freedom that is given by God. Human dignity is embedded in all rights. The Christian idea of freedom supports human rights, which are naturally inseparable from the individuals. Through the investigation of privacy and rights relating to personality, dealing with the problem of equality, we can conclude, that human rights must cover some social rights as well, based on the Christian approach.

Keywords: human rights, human dignity, Christianity, protection of privacy, equality, rights relating to personality, social rights

1 C. egyetemi docens PPKE JÁK; e-mail: dr.zsolt.balogh@gmail.com. 


\section{Bevezető}

Mértékadó természettudósok bátran kijelentik, hogy „a filozófia halott”. Bátran hirdetik, hogy „mindennemü nyitva hagyott kapu Isten előtt a nem eléggé konzekvens és koherens gondolkodás következménye. Bekövetkezett a »nagy trónfosztás «, a világmindenség olyan szinten értelmezhetővé vált, hogy nem marad benne hely Istennek." Ha ezen attitűd alapján közelítünk az emberi jogokhoz, akkor valóban az emberi fölényesség beteljesüléséről van szó. De az is egy közelítési mód, amely szerint a gyökerek a II. világháború utáni kijózanodásban keresendők, ${ }^{3}$ vagy többen politikai alapon közelítik meg, amennyiben azt állítják, hogy a liberális világeszme hozta felszínre, $\mathrm{s}$ annak (csak annak) elválaszthatatlan részét képezi.

E tanulmány elveti a fenti állításokat, s abból indul ki, hogy az emberi jogok a teremtett embertől elválaszthatatlan olyan természetes és elidegeníthetetlen jogok, amelyek tápláléka a keresztény szabadságeszme. ${ }^{4} \mathrm{~A}$ jogok a személynek mint teremtménynek a méltóságából fakadnak; e jogok megelőzik a társadalmat, és kötelezők reá nézve. ${ }^{5} \mathrm{Ha}$ a kereszténység és az emberi jogok kapcsolatát vizsgáljuk, akkor az emberi méltóságból kell kiindulnunk. Az emberi jogok keresztény szellemben történő átgondolása azért is szükségesnek mutatkozik, mert a társadalmi folyamatok erjedése már széles körben teszi bizonytalanná a korábban abszolútnak hitt értékeket: „A jog erkölcshordozó/értékvalósító fogalma helyébe az állam szankcionálta szabály elsőbbsége lépett. [...] Végső stádiumában a jog formális szabályrendszerré vált, ebben sem tökéletes, a logika és matematika tisztaságával szemben eseti, értékkiszolgáló jellegü rendszerré.” ${ }^{6}$ A személyre szabott jogalkotás mára már visszatetszést sem kelt, elfogadottá vált a törvény adta érdem.

\section{Az emberi méltóság mint Isten adta érdem}

Johannes Tauler középkori misztikus egyik prédikációjában a következőket mondta: „Az emberben bizonyos értelemben három ember van: egy állatias ember, aki érzékei szerint él; egy racionális ember; és végül a legmagasabb, istenformájú, istenképű

2 Stephen Hawking vonatkozó gondolatait idézi Török Csaba Az apokalipszis lovasai címü írásában [Vigilia, 85. (2020), 7. 484-485. 487.]

3 Ld. az ENSZ alapokmányát vagy az Emberi jogok egyetemes nyilatkozatát „az emberiség családja minden egyes tagja méltóságáról”.

4 „A szabadságot az emberek közötti kapcsolatokban gyakoroljuk. Minden Isten képmására teremtett emberi személy természetes joga, hogy szabad és felelös személynek tekintsék. Mindenki köteles megadni mindenkinek ezt a tiszteletet. Az emberi személy méltóságától elválaszthatatlan a szabadság gyakorlásának joga, különösen erkölcsi és vallási téren. A közjó és közrend keretein belül ezt a jogot polgárilag is el kell ismerni és biztosítani kell." A Katolikus Egyház Katekizmusa. Elérhető: https://archiv.katolikus.hu/kek, 1738. (A letöltés dátuma: 2020. 09. 29.)

5 Uo. 1930.

6 Zlinszky János: Emberi jogok és keresztény etika. Iustum Aequum Salutare, 5. (2009), 2. 127-132. 131. 
ember." Ez utóbbit figyelembe véve közelítjük meg a méltóságot. Az emberi méltóság az emberi minőség maga. A Katolikus Egyház társadalmi tanítása, ${ }^{8}$ illetve a katolikus katekizmus számos ponton hangsúlyozza az emberi méltóság minden embertől elvitathatatlan jogosultságát úgy is, mint a szabadság alapját. Nyilvánvaló, hogy az emberi méltóság több és más, mint jog. Azonban ha az emberi jogok rendszerébe kívánjuk behelyezni, szükséges a jogi összefüggések feltárása. Az alapjogi dogmatika az emberi méltóságot „anyajogként” kezeli, azaz minden más jog forrása. Az emberi jogokról nem beszélhetnénk méltósággal rendelkező ember nélkül. A jogi értelemben vett emberfogalom ${ }^{9}$ vagy „emberkép” 10 is az ember méltóságából indul ki, ez ad alapot a továbbgondolásra. De az emberi méltóság minden más alapjogban is ott van, szintén csak az alapjogi dogmatikára hivatkozva: minden más jog lényeges tartalmát jelenti. Az emberi méltóság az alapjogi rendszer kötőanyaga. Az emberi jogokat lehet korlátozni, de a korlátozás végső (és így semmilyen értelemben nem megengedhető) határa, hogy az nem sértheti az emberi méltóságot. De mit is rejt az emberi méltóság?

A test és a lélek dualizmusának alapjogi vetülete az élet(hez való jog), amely a testhez kapcsolódik, és az emberi méltóság, amely a lélekhez. E szerint különböztethetők meg az ember biológiai és társadalmi dimenziójához füződő jogok. ${ }^{11} \mathrm{Az}$ emberi méltóság a lélekben gyökerezik, ${ }^{12}$ azonban magának a léleknek a fogalma a jog által nehezen kezelhető. Az emberi méltósággal így egy olyan fogalom kerül be implicit módon az emberi jogok rendszerébe, amelyről mindenki tud, mindenki hallott, s amely az identitás alapja, eredője. Az alapjogok rendszerét tehát lehet ebből az aspektusból is szemlélni, lehet úgy tekinteni az emberi jogok rendszerére, hogy azt - az emberi méltóságon keresztül - áthatja az emberek ember voltának egésze. Sőt enélkül azt mondhatjuk, hogy az alapjogi katalógus önérdek és semmi más.

Amikor azt állítjuk, hogy az emberi jogok rendszere nem szétszórt garanciák öszszessége, hanem egy egységes és összetartozó értékrendszer, akkor állíthatjuk, hogy ez az értékrendszer szabadságra és önmegvalósításra született ember értékrendszere, de emellett mondhatjuk azt is, hogy a méltóságból eredő meggyőződésen alapuló ember - a hittel élő ember - értékrendszere. Tehát a vallási meggyőződéssel élő embert

7 Johannes Tauler: A hazatérés útjelzői. Budapest, Paulus Hungarus - Kairosz, 2002. 365.

8 Az Egyház társadalmi tanitása. Budapest, Szent István Társulat, é. n.

9 A magyar közjogban máig hatóan a jogi emberfogalom alapvető jellemzőit a 64/1991. (XII. 17.) AB határozat írta le.

10 Az Alaptörvény emberképe nem az elszigetelt egyéné, hanem a társadalomban élő felelős személyiségé. 3132/2013. (VII. 2.) AB határozat, Indokolás [95].

11 Magyarországon az egykori nem vagyoni kártérítés vagy a mai sérelemdíj is a társadalmi életben való részvétel elnehezüléséből indult ki, s most ott tart, hogy a lelki, önazonosságbeli sérelmek orvoslásának szimbolikus eszköze. Tehát az ember társadalmi dimenziója és lelki önazonossága megjelenik a „jog nyelvén”, egy jogintézményben. Az amerikai jogirodalomban már az 1800-as évek végén felmerült, hogy a lelki és érzelmi szenvedés nem vagyoni kártérítésre adhasson alapot.

12 „A minden emberben jelenlévő emberi lélek miatt rendelkezik minden ember méltósággal, ami áthatja a teljes lényüket, azaz szellemi (lelki), pszichés és testi létezésüket." Frivaldszky János: Emberi élet és méltóság. In Csink Lóránt - Schanda Balázs - Varga Zs. András (szerk.): A magyar közjog alapintézményei. Budapest, Pázmány Press, 2020. 501. 
nem távolítani kell az emberi jogok rendszerétől (mint olyantól, amely tőle idegen, mert az emberi jogi katalógus a társadalmat szétziláló erők bibliája), hanem épp ellenkezőleg, közelíteni kell felé, hiszen a Teremtő adta szabadságának az alapja, a jogok mélyén az emberi minőség, a méltóság lakozik. „Az emberi személy méltóságát alapvetően erkölcsi tudatának minősége határozza meg. Ennek mintegy előfeltétele az érzelmi érettség, és betetőződése a vallási tudat, ámbár e tényezők kölcsönösen és erőteljesen hatnak egymásra." ${ }^{13}$

Amikor az emberi jogok zabolátlan érvényesülésének kereteit szeretnénk megmutatni, sokszor mellétesszük, hogy igen, de ezek csak a kötelezettségek teljesítésével együtt érvényesek. Véleményem szerint a kereteket nem is az emberi jogoktól egészen más minőségű jogi kötelezettségek teremtik, ${ }^{14}$ hanem az önmagáért felelősséget vállaló ember életről való felfogása, emberi méltóságából eredő meggyőződése. Ez az, ami az alapjogok, emberi jogok valódi minőségét megteremti, hiszen ezen alapulva mutatkozik meg igazán minden alapjog érinthetetlen lényege. Az alapjogi katalógus így azért nem szétszórt garanciák összessége, mert együtt tarja „az emberi minőség”. A kötelezettségek teljesítését ellenpárként tenni azért sem szerencsés, mert aki nem teljesíti - nemcsak jogi, hanem (emberi) kötelezettségeit (otthagyja beteg szüleit, elhagyja gyermekeit stb.) is rendelkezik emberi méltósággal, másként fogalmazva ő is meghívott. S lehet, hogy épp emberi jogaival élve jut el oda, hogy a méltóságból eredő meggyőződés szerinti cselekedet felemeli. Tipikusan ilyen, amikor egy szituációban vagy egy esemény kapcsán rövid úton erős vallási meggyőződés alakul ki, amely a személyt aztán végigkíséri a további útján, azaz az emberi minőség részét képező gondolati szabadság, lelkiismereti önazonosság vagy itt: vallásszabadság juttatja a méltóságból fakadó szabadság és cselekedetek világába.

A fenti gondolatok egy másik oldalát szemlélve azt a kérdést kell feltennünk, hogy mit is jelent az emberi méltóság védelme. Mit véd az emberi méltóság? Nyilván védi az embert, az emberi minőséget, így kézenfekvő például, hogy a halálbüntetés mint büntetési nem tilos, minthogy az is, hogy aki emberi életre tör, az büntetendő. Az emberi méltóság és annak védelmi köre azonban ettől sokkal több. Míg az egyes jogok különböző aspektusokat jelenítenek meg az emberek életéből, ${ }^{15}$ addig az emberi méltóság az ember egészét érinti. Az emberi méltóság védelmi köre - a jog nyelvére lefordítható - funkcióiban jelenik meg, ugyanakkor e funkciók egymást áthatják, kiegészítik, feltételezik.

13 Kuminetz Géza: Egy tomista jog- és állambölcselet vázlata II. Az emberi önrendelkezés szükségszerü és ünnepélyes aktusa: személyes világnézet (vallás) alkotása. (Kísérlet az emberi jogok egy lehetséges megalapozására). Budapest, Szent István Társulat, 2018. 62.

14 Ha az alkotmányjogi kötelezettségeket nézzük (pl. honvédelmi, közteherviselési stb. kötelezettség), akkor ezek nem mondanak semmit arról, hogy a jogokkal való élésnek mi az alapja, tehát nem is lehetnek a jogokkal való élés előfeltételei. Ez így túl sematikusnak tűnik.

$15 \mathrm{Pl}$. a gyülekezési joggal való élés nyilvánvaló, hogy egyfajta véleménynyilvánításként az adott problémára koncentrál, amely az összejövetel tárgya, amíg a méltóság az egyén lényegét, immanens magját képezi, az egyén minden cselekedetét áthatja, pl. azt is, hogy mikor és hogyan él a gyülekezési jogával. 


\section{Az emberi méltóság védelmének egyes közjogi vetületei}

Az emberi méltóságnak az alapjogok védelmi rendszerében három nagy funkciója van: a megaláztatás elleni védelem, a személyiségvédelem és az egyenlőségi funkcióból eredő (hátrányos megkülönböztetés elleni) védelem.

\subsection{A megalázás elleni védelem}

A méltóság természetéhez talán legközelebb áló funkció a megaláztatás elleni védelem. E ponton nem lehet megkerülni azt a problémát, hogy az emberi méltóság védelméhez a jog által megkívánt objektív mérce nem vagy csak nagyon nehezen dolgozható ki. A probléma alapja az, hogy az emberi „érzékenység” más és más. Ami valakinek sérelmes és megalázó, másnak az meg sem üti az ingerküszöbét. Ilyen helyzetben a jog által megkívánt objektivitás csak szilárd, fogódzókkal teli szempontokkal biztosítható. Néhány ilyen szempont következik. ${ }^{16}$

Biztos, hogy sérti az emberi méltóságot az a szabályozás vagy joggyakorlat, amely dehumanizál: közvetve vagy közvetlenül kétségbe vonja az egyén (még rosszabb esetben egy nép vagy vallási csoport tagjai stb.) ember voltát, emberi minőségét. A dehumanizáló szabály, az ember ember voltának kétségbe vonása nyilvánvaló, hogy az emberi méltóság súlyos sérelmével jár. A népirtással foglalkozó irodalom egy része azt állítja, hogy a népirtás egyik előfeltétele az áldozatok dehumanizálása, azaz emberi lényük kétségbevonása, majd megtagadása. Tipikus formája ennek az ellenfél állatként való megnevezése. A következtetés adódik: mivel az ellenfelek nem emberek, a gátlásokat félre lehet tenni. ${ }^{17} \mathrm{~A}$ magyar joggyakorlatban is felmerült, hogy „[a]z állattal való azonosítás mindenkor dehumanizálja az érintett személyt, és ez az adott esetben alkalmas lehet az emberi méltóság megsértésére". ${ }^{18}$ Mindezeken túlmenve - bár távoli összefüggésben - a dehumanizáló szabályozásnak vagy joggyakorlatnak tekinthetjük azt is, ami az „emberkép” torzulását eredményezi. A cselekvési szabadsággal rendelkező, döntéseiért felelősséget vállaló polgár eszményének kétségbe vonása - különösen, ha ez egy meghatározott csoportot érint - elindíthatja ezt a káros folyamatot.

A megaláztatás elleni védelem körében kell szólni az úgynevezett tárgyként való kezelés tilalmáról. Az Immanuel Kant morálfilozófiai munkáiból a jogba átültetett instrumentalizálási tilalom szerint az embereket nem lehet eszköznek tekinteni. Megsérti az emberi méltósághoz való jogot az, aki személyeket puszta tárgyként kezel. Azonban Kantnak a morálfilozófiai munkássága során használt fogalma az embe-

16 Ld. Balogh Zsolt: Az emberi méltóság: jogi absztrakció vagy alanyi jog? Iustum Aequum Salutare, 6. (2010), 4. 35-45.

17 Ld. Bíró Gáspár: Az egyenlő méltóság elvérôl. Emberi méltóság korlátok nélkül. Budapest, Országgyúlés Hivatala, 2009. 70.

18 Választási ügyben merült fel a Kúria Kvk.I.37.441/2014/2. számú határozatában. A bíróság még hozzátette, hogy „Magyarországon a majommal való azonosítás azt eredményezi, hogy az állat leképeződött negatív tulajdonságai a jelöltekhez kötődnek (negatív kampány), miközben a kampányoló jelölt humán formában jelenik meg". 
ri méltóságról és a jogfilozófiai értelemben használt emberi méltóság fogalma nem kis nehézség árán egyeztethető össze. Különbséget kell tenni ugyanis az erényből eredő és a jogi kötelezettségek között, azaz a moralitás és a legalitás között. Az ember tárgyként való kezelésének tilalma során előszeretettel történik hivatkozás Kant $A z$ erkölcsök metafizikájának alapvetése című művére, ${ }^{19}$ annak is azon fél sorára, hogy „az embert [...] mindig célnak is, és ne pusztán eszköznek tekintsük”. A kanti morálfilozófia absztrakt méltóságfogalma a humanitásban, az emberként való létezésben ragadható meg, abban, hogy az emberi méltóság minden ember személyében az egész emberiséget jeleníti meg.

Az instrumentalizálási tilalom tekintetében a német joggyakorlatból lehet példákat hozni. A Német Szövetségi Alkotmánybíróság légi biztonsági törvénnyel kapcsolatos döntése az „eltárgyiasítással” érvelt. Úgy vélte, hogy az a lehetőség, amely szerint polgári repülőgépet terrorista támadás kivédése érdekében le lehet lőni, azon összefüggés okán sérti az emberi méltóságot, hogy az ártatlan utasokat puszta tárgyakká fokozza le. ${ }^{20}$ Korábbról említhetnénk az Erich Honecker-ügyet. ${ }^{21}$ Itt a bíróság úgy döntött, hogy a több mint nyolcvan esztendős, végső stádiumú rákbetegségben szenvedő Honecker elleni büntetőeljárás - figyelembe véve halála közeli bekövetkeztét - nem érheti el legitim célját. Az eljárás további folytatása azt eredményezné, hogy a gyanúsítottat puszta eszköznek tekintenék, ami sérti az emberi méltóságot. ${ }^{22} \mathrm{~A}$ hazai joggyakorlatban az eszközként, tárgyként való kezelés mint az emberi méltóság sérelmének szempontja ilyen tisztán nincs jelen, jóllehet vannak ügyek, amelyekben valójában mégiscsak ez a kérdés. Magához a halálbüntetést eltörlő alkotmánybírósági határozathoz tartozó párhuzamos indokolás szerint „van egy abszolút határ, amelyen sem az állam, sem más emberek kényszerítő hatalma nem terjedhet túl, vagyis az autonómiának, az egyéni önrendelkezésnek egy mindenki más rendelkezése alól kivont magja, amelynél fogva - a klasszikus megfogalmazás szerint - az ember alany maradhat, és nem válik eszközzé vagy tárggyá." ${ }^{33} \mathrm{~A}$ tárgyként való kezelés tilalma az emberi méltósággal teremtett ember védelmét jelenti.

A megaláztatás - s így az emberi méltóság - elleni védelem körébe sorolandó továbbá annak tiltása, hogy az egyén kiszolgáltatott helyzetével más vagy mások viszszaéljenek (egy veszélyeztetett helyzet mások általi kihasználása). A jogrendszerben számos olyan jogszabály található, amely az emberi méltóság védelmét magába a normába is belefoglalja. Legszembetűnőbb az egészségügyi törvény, amely a betegjogok között külön - és részletesen - az emberi méltósághoz való jogot is „szabályozza". (Idetartozik például a szeméremérzet védelme, a méltányolható várakozás stb. - a törvény szerint. ${ }^{24}$ Más szabályok lényegében megismétlik az emberi méltó-

19 Immanuel Kant: Az erkölcsök metafizikájának alapvetése. Budapest, Gondolat, 1991. 62-68.

20 BVerfGE 115., 118., (154, 157).

21 Az egykori Német Szocialista Egységpárt főtitkára ellen a nyugatra szökni próbáló személyek lelövése miatt indult büntetőeljárás.

22 BerlVerfGE NJW 1993, 515.

23 Ld. Sólyom Lászlónak a 23/1990. (X. 31.) AB határozathoz füzött párhuzamos indokolását.

24 Az egészségügyről szóló 1997. évi CLIV. törvény 10. \$. 
sághoz való jog védelmének alkotmányi parancsát. A humángenetikai kutatásokról, vizsgálatokról, a biobankok működéséről szóló törvény preambulumában mondja ki, hogy ezen eljárások során az emberi méltóság fokozott védelme indokolt. ${ }^{25} \mathrm{~A}$ szociális törvény szerint a hajléktalan személyek elhelyezésekor különös figyelemmel kell lenni az emberi méltóság védelmére. ${ }^{26}$ Más törvény a közcélú adománygyüjtéshez kapcsolódva mondja azt, hogy az adománygyüjtés nem járhat az adományozók zaklatásával, az emberi méltóság sérelmével, ${ }^{27}$ további szabály szerint rendörségi fogdában a fogvatartottakkal az emberi méltóság tiszteletben tartásával kell bánni. ${ }^{28}$ Látható tehát, hogy az emberi méltóság - bár különböző megfogalmazásokban - rendre olyan jogi szabályokban tűnik fel, amelyek vonatkozó eseteiben feltételezhető, hogy az egyén $k i$ szolgáltatott helyzetbe kerül, amikor egyenlőtlen kommunikációs vagy egyéb viszony alakul(hat) ki a felek között (még inkább, ha az egyik fél az állam). Tehát maga a jogalkotó is feltételezi az aszimmetrikus viszonyt, ezért szükségesnek tartotta az emberi méltóság védelmét rögzíteni, aminek célja a kiszolgáltatott fél „helyzetének megemelése", az aszimmetria megszüntetése. A kiszolgáltatott helyzetben előállt méltóságbeli sérelemről (a veszélyeztetettségről, a veszélyeztetettség kivédéséről) az alkotmánybírósági gyakorlatból is lehet példát hozni. Mint fentebb láttuk, a jogrendszer e szituációkban az emberi méltóság védelmét nyomatékosítja. Az alkotmánybírósági döntések közül a kamerás megfigyelés kapcsán hozott egyik határozat - a gyakorlatra egyáltalán nem jellemző módon - az emberi méltóságot (mégpedig az emberi méltósághoz való jogot) közvetlenül alkalmazta a megítélendő szabályozásra. „Az a törvényi feltétel, miszerint az érintett személynek az alapjogi korlátozáshoz ráutaló magatartással történő hozzájárulása akár ahhoz is elegendő, hogy őt intim helyzetben megfigyeljék, sérti az emberi méltósághoz való alkotmányos alapjogot."29

E körben további szempontnak tekinthetjük, hogy az emberi méltóság sérelmét jelenti, ha észszerủ indok alapján igazolható, hogy az egyén személyiségének lényegét illetően erős sértés áldozatává vált. Ez a legképlékenyebb szempont, s az emberi érzékenység függvényében ez ragadható meg legkevésbé objektív mércékkel. ${ }^{30} \mathrm{Az}$ erre

25 A humángenetikai adatok védelméről, a humángenetikai vizsgálatok, valamint a biobankok mủködésének szabályairól szóló 2008. évi XXI. törvény preambulum.

26 A szociális igazgatásról és a szociális ellátásról szóló 1993. évi III. törvény 94/H. \$ (1) bek.

27 A közhasznú szervezetekről szóló 1997. évi CLVI. törvény 12. \$ (1) bek.

28 A rendőrségi fogdák rendjéről szóló 19/1995. (XII. 13.) BM rendelet 1. $\mathbb{\$}$ (2) bek.

29 36/2005. (X. 5.) AB határozat, ABH 2005, 401-402. Azt gondoljuk, hogy e határozat érvelése a dogmatikában félrecsúszott. Se előtte, se utána nem alkalmazta az Alkotmánybíróság az emberi méltósághoz való jog mint alapjog megsértését közvetlenül a jogszabályra.

30 Az egyéni érzékenység és az egyén személyiségének lényegét érintő sértés számos aspektusban felmerülhet. Így pl. a vallási, meggyőződésbeli identitás kapcsán hívja fel Koltay András az Európa és a feszület jele címủ tanulmányában a figyelmet arra, hogy a második Lautsi-döntéshez írt párhuzamos indokolásában Ann Power bírónő úgy vélekedett, hogy a puszta „sérelem”, a nem kívánt közlés általi „sértettségérzés” nem éri el azt a szintet, amellyel szemben a magát sértettnek érző egyén számára a bíróság orvoslást nyújthat. Koltay András: Európa és a feszület jele. A Lautsi and Others v. Italy ügy alapvető kérdéseiről. In Tattay Levente - Pogácsás Anett - Molnár Sarolta (szerk.): Pro vita et scientia. Ünnepi kötet Jobbágyi Gábor 65. születésnapja alkalmából. Budapest, Szent István Társulat, 2012. 124-150. 128. 
vonatkozó szempontok szerint a megalázást úgy kell érteni, hogy annak során a személynek racionális indoka kell legyen arra, hogy önbecsülésében sértve érezze magát. A kedvezőtlen körülmények önmagukban nem, csak emberi cselekedetek vagy mulasztások jelenthetik a méltóság megsértését. A megalázásnak minősítés feltétele továbbá, hogy harmadik fél által is érthető - és igazolt - okok álljanak fenn. Ilyen sértő helyzetekkel is számol a magyar jogrendszer. A szabálysértési, illetve a büntető joganyagban az emberi méltóság megsértését megvalósító tipikus magatartásformák a vallásgyakorlás jogának megsértése, a gyermeki koldulás vagy például az alárendelt megsértése a katonai büncselekményeknél. Könnyen belátható, hogy például egy vallási szertartás megzavarása a hívők személyisége lényeges megsértésének minősül.

\subsection{Személyiségvédelem}

Az emberi méltóság a jog világában a személyiségvédelmet (is) jelenti. Mind az alkotmányjog, mind a polgári jog, mind a büntetőjog eszköztárában szép számmal szerepelnek (jog)intézmények a személyiségvédelem érdekében. Az alkotmányjogi és polgári jogi eszközök közel kerülhetnek egymáshoz, bár más-más jogi vetületről van szó. Az alkotmányjog az emberi méltóságból fakadó személyiségvédelmet három nagy jogcsoporton keresztül jeleníti meg: egyrészt az önazonossághoz való jog(csoport), másrészt az önrendelkezéshez való joghoz kapcsolódó alapjogok, harmadrészt a magánszféra jogai tartozhatnak ide. Ezek a jogok és az azokból fakadó egyéb jogok egymást feltételezik, egymást kiegészítik, továbbá a védelem körében újabb és újabb jogok is levezethetők a személyiség védelme érdekében.

Az önazonossághoz való joggal találkoztunk úgy is, mint a személyiség integritásához való jog vagy erkölcsi integritáshoz való jog, más megfogalmazásban mint tilalom: a személyiség fizikai vagy erkölcsi megtörésének tilalma. Nyilvánvaló, hogy senki nem kényszeríthet mást arra, s nem hozhat olyan helyzetbe, hogy meghasonuljon önmagával. Az önazonossághoz elválaszthatatlanul kapcsolódik a vallási önazonosság, a vallási, lelkiismereti meggyőzés. A vallási vagy lelkiismereti meggyőződés megválasztása (adott esetben megváltoztatása) abszolút jog, senki által nem érinthető. ${ }^{31} \mathrm{Az}$ önazonosság része továbbá a nemzeti vagy etnikai kisebbséghez tartozás és ennek megvallásának, nyilvánosságra hozásának szabadsága. Amikor valaki az önazonosságának a védelmére (sérelmére) hivatkozik, a lelkiismereti ok valóságtartalma nem vizsgálható: az emberi méltóság érinthetetlen. A jog világában az önazonosság védelmének hagyományos eszköze a régi nem vagyoni kártérítés, ${ }^{32}$ a mostani a sérelemdíj jogintézménye. Lelki, önazonosságbeli sérelmek esetén nem azért perel valaki adott esetben tíz vagy száz forint értékben, mert erre az összegre szüksége van, hanem azért, hogy a bíróság állapítsa meg a jogsértést, és a szimbolikus kártérítés fejezze ki, hogy az önazonosságbeli sérelem anyagilag nem kompenzálható (a lelki,

31 Ennek az „intimitását” nagyon jól kifejezi Pilinszky János Zsoltár címủ versének utolsó strófája: „S aki egy vánkosra borulva / nem érzi magát egyedül: / valóban nincs egyedül." 
önazonosságbeli sérelem nem szűnik meg anyagi hozzájárulással, az emberi méltóság megsértése nem orvosolható anyagi javakkal, a kettő nem kompatibilis). A jogintézménynek tehát egyértelmủen erkölcsi értékalkotó funkciója van amellett, hogy a személyiségvédelem jogi elismerése is kifejeződik benne. Végezetül meg kell jegyeznünk, hogy az önazonosság védelmének dinamikusnak kell lenni, azaz tekintettel kell lenni a személyiségfejlődésre, a személyiség változására. Ahogy az önazonosság, úgy az önrendelkezés szabadsága is átfogja a személyiség egészét. Ugyanakkor az önazonosságban megcsillanó emberi méltóság kívülről érinthetetlen, ám az önrendelkezési vagy más néven cselekvési szabadság igencsak korlátok közé szorítható. Korlátok közé szorítható elsősorban más vagy mások jogainak védelmében, adott esetben korlátozható az egyén önveszélyessége esetén is. ${ }^{33}$ Tehát a cselekvési szabadság nem korlátlan jogosultság. Bár szabadon eldönthetem, hogy miként alakítom életem, ez csak a különböző keretek tiszteletben tartásával történhet. Mindenkire érvényesek a jogi keretek, de vannak más keretek is. Erkölcsi keretek, léteznek a vallási normák által felállított keretek, különböző közösségek önmagukra érvényes normái stb. A különböző kereteket akár szankciós korlátoknak is nevezhetjük, hiszen ha az egyén - önrendelkezési szabadságával élve - ezeken átlép, akkor a különböző rendszerek (például a jogrendszer) nem maradnak közömbösek.

Az önrendelkezés keretén belül kell szólni arról, hogy az emberi jogok garantálása, az emberi jogok által nyújtott szabadság - az önrendelkezés révén - magában foglalja a joggal való nem élés szabadságát is, a jogról való lemondást. S vissza is kanyarodtunk a különböző rendszerek által felállított, létrehozott keretekre: a jogról való lemondás révén adott esetben egy vallási vagy erkölcsi normarendszer szabályainak a betartása valósul meg. Helyes élet valósul meg, ha az önrendelkezésnek e különböző keretei összhangban vannak a személy önazonosságával, a szabályok betartása nem kényszer, hanem belső meggyőződés eredménye. Az önrendelkezés útján történik a személyiség szabad kibontakozása, az önmegvalósítás, amely szintén elválaszthatatlan az emberi méltóságtól.

Az emberi méltóság a személyiségvédelmen keresztül védi a magánszférát is. A magánszféra védelme egy elvitathatatlan emberi igény, annak jogi védelme is ebből az „ősi igényből” táplálkozik. A magánszféra jogi védelmének kialakulása elsősorban az amerikai jogfejlődés eredménye, az európai jogrendszerek onnan vették át. ${ }^{34}$ De a megjelenés időbeliségétől függetlenül az a jog, hogy békén hagyjanak (right to be

33 Nagyon messzire vezet, $\mathrm{s}$ alapos kutakodást igényel, hogy az állam vagy más mennyiben és mikor védheti meg az egyént önkárosító tevékenységétől. Szélsőséges esetekben mindenképp, ezért büntetendő pl. az öngyilkosságban való közremüködés vagy a kábítószerrel való visszaélés. Ugyanakkor már nem ilyen egyértelmű és hosszas társadalmi vita volt a művi meddővé tétel megengedhetőségéről, megengedésének feltételeiről. A Katolikus Egyház a tiltás mellett állt ki. De önkárosító tevékenység a dohányzás vagy az alkoholfogyasztás is, ahol az az ellen való fellépés már más megítélés alá esik. Mindezekben a kérdésekben felsejlik az önrendelkezés korlátozása, korlátozhatósága, annak határai - az individuum háttérbe szorítása a közösséggel szemben.

34 A magánszféra meghatározásának kiindulópontja Samuel D. Warren és Louis D. Brandeis nevéhez füződik, akiknek 1890-ben jelent meg The Right to Privacy (A magánszférához való jog) című műve [Harvard Law Review, 4. (1890), 5. 193-220.]. 
let alone), minden korban aktuális. Az emberi méltóság védelmi körét tekintve ugyanakkor nincsenek lehatárolható szélei a magánszférához való jognak, hiszen a magánszférát védi az önazonosság, az önrendelkezés, sőt az emberi jogok egész rendszere. Biztos alap tehát az emberi méltóság, amely minden jogban jelen van, a jogok pedig feltételezik és kiegészítik egymást. Ha azonban szorosan a magánszférához kapcsolódó jogokat nézzük, akkor ilyen a jó hírnévhez való jog; a magánélet, a családi életét, az otthon vagy a személyek kapcsolattartásának szabadsága, ilyen a hozzánk kötődő információk kontrolljához való jog, azaz a személyes adatok védelme is. ${ }^{35}$

Minden ember egyedi és megismételhetetlen - fakad az emberi méltóságból -, így a személyiségnek is meghatározhatatlanul sok összetevője van, személyiségekként más-más prioritásokkal. A jog csak a legjellemzőbbeket ragadja meg, de mint fentebb vázlatosan bemutattuk, ezek a „jogiasított”, nevesített összetevők is egymást feltételezik, egymásba kapaszkodnak, helyettesítik egymást. A minden ember egyenlő méltóságának társadalmi-jogi lenyomata a nevesített jogok rendszere, amely sohasem zárt, mindig fogékony kell hogy legyen az újabb és újabb akceptálható összetevőkre. Ezért soha nem lezárt a személyiségvédelem rendszere. Természetesen a személyiség lényegétől elválaszthatatlan identitáselem(ek) - s ilyen a vallási identitás - mindig is a személyiségvédelem központi magja marad(nak).

\subsection{Egyenlöség}

Az emberi méltóság megaláztatás elleni védelem, személyiségvédelem funkciói mellett szólni kell az egyenlőséget biztosító összetevőjéről is. Az emberi méltóság és a minden ember egyenlősége kéz a kézben jár. Az egyenlőség a méltóságban való egyenlőséget jelenti, az ember lényegére mutat rá. A teremtett ember egyenlősége alapján az emberi életek értéke egyforma. „Az egy Isten képmására teremtett összes ember ugyanazzal az értelmes lélekkel, ugyanazzal a természettel és ugyanazzal az eredettel bír. [...] Az emberek közötti egyenlőség lényegileg a személyi méltóságukra és a belőle fakadó jogokra támaszkodik" - mondja a Katolikus Egyház Katekizmusa, ${ }^{36}$ de hasonló megfogalmazást máshol is találhatunk: „Magától értetődőnek tartjuk azokat az igazságokat, hogy minden ember egyenlőként teremtetett, az embert Teremtője olyan elidegeníthetetlen jogokkal ruházta fel, amelyekről le nem mondhat." ${ }^{\prime 37}$ Időben csúszkálva s csak szemelgetve érdemes felidézni a következőket is: „Az egyenlő méltósághoz való jog az élethez való joggal egységben azt biztosítja, hogy ne lehessen emberi életek értéke között jogilag különbséget tenni. Emberi méltósága és élete mindenkinek érinthetetlen, aki ember, függetlenül fizikai és szellemi fejlettségétől, illetve

35 Ld. Alaptörvény VI. cikk (1) bek.

36 A Katolikus Egyház Katekizmusa. Elérhető: https://archiv.katolikus.hu/kek, 1934., 1935. (A letöltés dátuma: 2020. 09. 29.)

37 Az Amerikai Egyesült Államok Függetlenségi nyilatkozata (1776). 
állapotától, és attól is, hogy emberi lehetőségéből mennyit valósított meg, és miért annyit." ${ }^{38}$

Az emberi méltóság egyenlőséget védő funkciója maga a méltóság lényege, nem beszélhetnénk az emberi életek értékének azonosságáról a méltóságbeli egyenlőség nélkül. A méltóságbeli egyenlőség mellett az emberek természetesen különböznek egymástól. A lényegi különbözőségeket ha kiemeljük, ezek a jog nyelvén az úgynevezett védett tulajdonságok. Amikor egyenlőségről vagy annak másik oldaláról, a hátrányos megkülönböztetés tilalmáról beszélünk - akár alkotmányokat, nemzetközi emberi jogi dokumentumokat vagy más, nem jogi, de az egyenlőséggel foglalkozó nyilatkozatokat nézünk -, mindig találkozunk egy rövidebb-hosszabb felsorolással, amely külön is kiemeli, hogy milyen szempontok szerint tilos a megkülönböztetés. A legrövidebb felsorolás a nem, a faj, a bőrszín, a társadalmi helyzet, a nyelv, a vallás vagy a politikai vélemény szerinti megkülönböztetés tilalma.

Ez a külön felsorolás a jogi védelmet megduplázza, hiszen például a férfiak és a nők egyenjogúsága mint szabály megjelenik újra a nemek szerinti megkülönböztetés tilalmában, vagy például a vallás szerinti megkülönböztetés tilalmát (azaz hogy mindenki szabadon gyakorolhatja vallását) a vallásszabadság jogánál külön is rögzítik. Anélkül, hogy a jelölt „védett tulajdonságokat” külön is elemeznénk, néhány szót szólnánk a férfiak és a nők közötti egyenlőségről. Véleményünk szerint a kereszténység lényegéhez tartozik ez az egyenlőség. Akár a szinoptikus evangéliumokat, akár János evangéliumát olvassuk, a nők és a férfiak egyenlőként való említése olyan természetességgel jelenik meg, mint ahogy abban a korban ez egyáltalán nem volt természetes. ${ }^{39}$ Nemcsak a halálban, hanem a méltóságában is mindenki egyenlő - az emberi méltóságról vallottaknak így minden kornak szóló üzenete van.

Az emberi méltóság által közvetített egyenlőség a megkülönböztetés tilalma útján külön értelmet is nyer. „Amikor az ember megszületik erre a világra, nem rendelkezik mindennel, amire szüksége van testi és lelki életének fejlődéséhez. Szüksége van másokra. Különbségek jelennek meg, amelyek életkorhoz, testi képességekhez, értelmi és erkölcsi adottságokhoz, gazdasági tevékenységhez és vagyonhoz kötődnek. A talentumok nem egyformán kerülnek szétosztásra." ${ }^{40}$ Mivel a nem egyenlők egyenlöként való kezelése még nagyobb egyenlőtlenségeket eredményez, mégiscsak szükség van a jog általi különbségtételre. Ennek a különbségtételnek azonban igazodni kell az egyén helyzetéhez, a társadalmi valósághoz. Ahogy az egyenlőségi követelmény az igazságosságot is tükrözi, úgy a szükséges különbségtétellel szemben is alapvető elvárás, hogy az jelenítse meg a társadalmi igazságosságot. A kirívó egyenlőtlensé-

38 A 23/1990. (X. 31.) AB határozat nyomán a 64/199. (XII. 17.) AB határozat.

39 A tizenkét tanítvány mellett sok nő is együtt volt Jézussal, akik a későbbi apostolokkal együtt Jézus legszűkebb tanítványi köréhez tartoztak (pl. Lk 8,1-3; Mt 27,55). Sok történet, példabeszéd fó alakja nő, ld. pl. a szamáriai asszonyt (Jn 3,22-36). Ugyanígy feltünnek az asszonyok az apostolok cselekedeteiben is, ahol az apostolokkal együtt imádkoztak (Apcsel 1,14) stb.

40 A Katolikus Egyház Katekizmusa. Elérhető: https://archiv.katolikus.hu/kek, 1939. (A letöltés dátuma: 2020. 09. 30.) 
gek megszüntetése, a szegények megsegítése a kereszténység lényegéhez tartoznak, ${ }^{41}$ a Katolikus Egyház következetesen hirdeti, hogy az egy emberi család tagjai vagy népei közötti kirívóan nagy gazdasági és társadalmi egyenlőtlenségek botrányt okoznak, és ellenkeznek a társadalmi igazságossággal, a méltányossággal, az emberi személy méltóságával, valamint a társadalmi és a nemzetközi békével.

Az emberi méltóságból következő egyenlőség a javak szétosztásának igazságosságát követeli. A jog nyelvén vagy akár az Egyház szociális tanításai szerint ${ }^{42}$ ez jogosultságok megteremtését írja elő az emberhez méltó élet megteremtésére mindenki számára. A jog nyelvén: „A szociális biztonsághoz való jog a szociális ellátások összessége által nyújtandó olyan megélhetési minimum állami biztosítását tartalmazza, amely elengedhetetlen az emberi méltósághoz való jog megvalósulásához. ${ }^{” 3}$ Az egyházi tanítás szerint: „Amikor az ember jogairól akarunk szólni, mindjárt kezdetkor ki kell jelenteni, hogy az embernek joga van az élethez, joga van a testi épséghez, joga van mindazon eszközökre, amelyek szükségesek a tisztességes élethez: ilyenek elsősorban a táplálék, a ruházat, a lakás, a pihenés, a gyógykezelés, végül az államtól nyújtandó szükséges szolgáltatások, amelyekkel az egyénről gondoskodik." ${ }^{44}$

Az emberi méltóságból tehát nemcsak a szabadságjogok nőnek ki, hanem a szociális jogok világa is az emberi méltóságban gyökerezik. Véleményem szerint tévesek azok a megfontolások, amelyek az emberi jogok alatt csak a klasszikus szabadságjogok katalógusát értik. Épp az emberi méltóság egyenlőségi funkciójából fakadnak a második generációs jogok, s ezeknek a jogoknak (jogosultságoknak) az érvényesülése helyenként fontosabb is. A klasszikus szabadságjogok és a szociális jogok feltételezik egymást, már csak a közös alap, az emberi méltóság „megvalósulása” miatt is. A hátrányos megkülönböztetés tilalmának érvényesülése korántsem jelenti az egyenlőség megvalósulását. A javak arányos elosztása az államilag szervezett társadalom elsőrendű célja kell legyen. Csak így fejezhető ki, hogy a közösségben élő emberek nem elszigetelt individuumok, nemcsak magunkért kell vállalni a felelősséget, mint ahogy ezt korábban már említettük, de ugyan ilyen fontos az egymásért vállalt és viselt felelősség is. Ennek több szintje is van, a közösségek jellegéhez igazodóan többféle elvárás is támasztható. Nem elég a társadalmi újraelosztás rendszereibe befizetni, hanem mindenkinek személy szerint, akár tevőlegesen is részt kell vállalnia abban, hogy a szociális biztonság mindenki számára valósággá váljon. Szolidaritás vagy másként fogalmazva: testvériség is következik abból, hogy az ember, méltósággal rendelkező személy. Nem segélyekről van szó, hanem az anyagi javakban dúskálók önmérsékletéről és a rászorultak részére olyan lehetőségek biztosításáról, amellyel önmaguk tudnak magukon segíteni. S mivel ez a probléma globális, ennek megoldására is globális

41 Ld. pl. a gazdag ifjú történetét (Mk 10,17).

42 A szociális enciklikák közül mintegy „ősforrásként” hivatkozhatunk XIII. Leó pápa Rerum novarum (1891) enciklikájára. Elérhető: https://regi.katolikus.hu/konyvtar.php?h=125 (A letöltés dátuma: 2020. 09. 29.)

43 32/1998. (VI. 25.) AB határozat.

44 XXIII. János pápa: Pacem in terris (1963). Elérhető: https://regi.katolikus.hu/konyvtar.php?h=122, 11. pont. (A letöltés dátuma: 2020. 09. 30.) 
eszközök kellenek. A kereszténység több ezer éve e probléma mellett él, s minden korban kínál globális megoldást. ${ }^{45}$

\section{Zárógondolatok}

Nehéz helyzetben van a szerző, amikor a kereszténység és az emberi jogok kapcsolatáról ír. Nehéz helyzetben van, mert bár önmagában a jog nyelvezetét használva biztos talajon áll, akár az emberi jogokról általában, vagy akár az egyes jogokról van szó: ismertek a sztenderdek, megszokott a fogalmi kultúra. Azonban amikor e fogalmi kultúrából ki kell lépni, és más tudományterületekbe is kapaszkodva kell a gondolatait elfogadható formába önteni, a talaj bizonytalanná válik. Mindenesetre e tanulmány lehetőséget adott, hogy kísérlet szintjén ugyan, de ötvözzük a jogi ismereteket azokkal a gondolatokkal, könyvekkel, amelyek a magánélet kedves olvasmányai. Reményeim szerint a bizonytalan talaj ellenére az olvasó talál olyan gondolatot, hivatkozást, amely alapján e cikket megőrzi jó emlékezetében.

\section{Irodalomjegyzék}

A Katolikus Egyház Katekizmusa. Elérhető: https://archiv.katolikus.hu/kek (A letöltés dátuma: 2020. 09. 29.)

Az Egyház társadalmi tanítása. Budapest, Szent István Társulat, é. n.

Balogh Zsolt: Az emberi méltóság: jogi absztrakció vagy alanyi jog? Iustum Aequum Salutare, 6. (2010), 4. 35-45.

Benedek, XVI., pápa: Caritas in veritate (2009). Elérhető: https://regi.katolikus.hu/konyvtar. php?h=397 (A letöltés dátuma: 2020. 09. 29.)

Bíró Gáspár: Az egyenlő méltóság elvéről. Emberi méltóság korlátok nélkül. Budapest, Országgyülés Hivatala, 2009.

Frivaldszky János: Emberi élet és méltóság. In Csink Lóránt - Schanda Balázs - Varga Zs. András (szerk.): A magyar közjog alapintézményei. Budapest, Pázmány Press, 2020. 445-535.

János, XXIII., pápa: Pacem in terris (1963). Elérhető: https://regi.katolikus.hu/konyvtar.php?h=122 (A letöltés dátuma: 2020. 09. 29.)

Kant, Immanuel: Az erkölcsök metafizikájának alapvetése. Budapest, Gondolat, 1991.

Koltay András: Európa és a feszület jele. A Lautsi and Others v. Italy ügy alapvető kérdéseiröl. In Tattay Levente - Pogácsás Anett - Molnár Sarolta (szerk.): Pro vita et scientia. Ünnepi kötet Jobbágyi Gábor 65. születésnapja alkalmából. Budapest, Szent István Társulat, 2012. 124-150.

Kuminetz Géza: Egy tomista jog-és állambölcselet vázlata II. Az emberi önrendelkezés szükségszerü és ünnepélyes aktusa: személyes világnézet (vallás) alkotása. (Kísérlet az emberi jogok egy lehetséges megalapozására.) Budapest, Szent István Társulat, 2018.

Leó, XIII., pápa: Rerum novarum (1891). Elérhető: https://regi.katolikus.hu/konyvtar.php?h=125 (A letöltés dátuma: 2020. 09. 29.)

45 Nagyon tanulságos megállapításokkal és megoldási módokkal szolgál nemrégről XVI. Benedek pápa Caritas in veritate (2009) enciklikája. Elérhető: https://regi.katolikus.hu/konyvtar.php?h=397. (A letöltés dátuma: 2020. 09. 30.) 
Tauler, Johannes: A hazatérés útjelzői. Budapest, Paulus Hungarus - Kairosz, 2002.

Török Csaba: Az apokalipszis lovasai. Vigilia, 85. (2020), 7. 484-485.

Warren, Samuel D. - Louis D. Brandeis: The Right to Privacy. Harvard Law Review, 4. (1890), 5. 193-220. DOI: https://doi.org/10.2307/1321160

Zlinszky János: Emberi jogok és keresztény etika. Iustum Aequum Salutare, 5. (2009), 2. 127-132. 